\title{
Pemanfaatan Sumber Daya Alam Hayati Sebagai Objek Wisata Dan Tingkat Kesejahteraan Masyarakat Sekitar Lokasi Wisata
}

\author{
Dian Minasari Siregar ${ }^{1}$, Sri Ramadhani ${ }^{2}$, Annio Indah Lestari Nasution ${ }^{3}$ \\ 1,2,3 Universitas Islam Negeri Sumatera Utara \\ Corresponding Author: Minasaridian0@gmail.com
}

ABSTRACT

Tourism activities are activities that involve various interests (multisectoral) and are closely related to global economic developments. In addition, tourism is an activity that relies on the utilization of the potential of the natural resources that exist in each object and tourist attraction while still guided by balance and preservation (without destroying the natural potential they have). In this paper, it is about the use of biological natural resources as a tourist attraction and the level of welfare of the community around the Pematang Johar tourist site. Therefore, the purpose of this study is to identify the physical carrying capacity and potential of rice field tourism in supporting tourism activities and find out whether the construction of rice field tourism facilities is able to provide welfare for the community around tourist sites. This study uses a type of field research (Field Research) with a research nature this is descriptive qualitative. The results of the study indicate that the physical carrying capacity and potential of rice field tourism in supporting tourism activities are human resources who play an important role in managing tourist villages, adequate facilities and infrastructure such as worship facilities and public toilets as well as infrastructure to the location is also quite good with good road access. And good promotion. The construction of rice field tourism facilities is able to provide welfare for the people around the tourist sites, which can be seen from the number of jobs and reducing unemployment in the tourist village of Pematang Johar itself, which is evident from the increasing economy of the income of the people around the location and the growing socio-cultural value.

Keywords

Natural Resources, Tourism Objects, Level of Welfare, Tourist Locations

\section{PENDAHULUAN}

Manusia tidak mampu berdiri sendiri, tanpa bersosialisasi dengan manusia lain, hal pertama untuk melengkapi keperluan manusia ialah berinteraksi pada manusia lainnya dengan aktivitas ekonomi. Ilmu ekonomi adalah cabang pengetahuan untuk mengetahui seperti apa manusia melengkapi kebutuhannya, pribadi, sekunder, maupun lainnya. Aktivitas ekonomi itu berupa aktivitas memproduksi, menyalurkan serta menjual jasa lainnya untuk mendapatkan uang atau harta benda menjadi alat agar menjadi penentu kemakmuran manusia. Bagian wisata ialah suatu kemampuan ekonomi rakyat yang harus dilakukan pengembangan untuk peningkatan 
kemakmuran rakyat dalam membangun daerah. Berikut dilaksanakan pada seluruhnya serta rata hingga harus melakukan pembangunan yang terorganisasi. Selain itu, pemahaman kepariwisataan meliputi usaha memberdayakan, objek serta penarik wisatawan serta bermacam usaha lainnya.

Aktivitas wisata ialah aktivitas yang berhubungan dengan pentingnya (multi sektoral) yang berhubungan pada pengembangan ekonomi umum. Kemudian, pariwisata adalah aktivitas yang bertumpu pada memanfaatkan SDA yang ada di objek serta menarik wisatawan berpacu dengan penyeimbangan serta melestarikan. Kemudian perlu meningkatkan penjualan serta memasarkan dan meningkatkan akademik dan melatih pariwisata, menyediakan infrastruktur yang berkualitas serta melancarkan aktivitas wisata. Obyek wisata merupakan komoditas yang banyak dimanfaatkan oleh suatu negara. Dengan adanya obyek wisata maka potensi ekonominya sangat besar, seperti adanya pedagang yang menjajakan aneka makanan dan minuman, menyediakan alat transportasi, dan berbagai jasa lainnya. Dengan demikian sektor pariwisata juga dapat dipengaruhi oleh kondisi ekonomi seperti kondisi moneter, tingkat pendapatan rata-rata penduduk, tingkat daya beli masyarakat, dan lain-lain.

Kegiatan pariwisata sendiri memiliki multiplier effect yang bermanfaat bagi sektor lain. Sebagian besar daerah melakukan perkembangan aktivitas pariwisata bertujuan agar dapat membuat peningkatan pemasukan daerah dan meningkatkan kemakmuran rakyat sekitar desa wisata. Penelitian yang sudah pernah dilakukan memperlihatkan yakni organisasi BUMDes Johar Mandiri Jaya pada peningkatan pemasukan rakyat pada Pematang Johar ada di kriteria bagus dengan skor sebesar $81,99 \%$. Hal tersebut memperlihatkan yakni peran BUMDes Johar Mandiri Jaya pada peningkatan pemasukan rakyat pada Pematang Johar sangat bagus. Adapun cara yang digunakan untuk melihat kesejahteraan masyarakat sekitar desa wisata yaitu melalui pengembangan desa wisata harus diarahkan pada pelestarian budaya, tradisi, dan lingkungan, pengelolaan yang transparan juga harus dilakukan, ada adalah legalitas kelembagaan dan kelompok pengelola dari desa wisata, menjalin kerjasama yang baik dengan pemerintah. . Akademisi, sektor swasta, media dan masyarakat.

Selain itu, juga harus memiliki nilai kontribusi terhadap kesejahteraan sosial, mendorong partisipasi aktif antara masyarakat dan wisatawan.

Pada kenyataannya, kesejahteraan hidup memiliki banyak indikator keberhasilan yang dapat diukur, sehingga banyak metode dan pendekatan yang digunakan saat ini dalam mengukur tingkat kesejahteraan masyarakat. Ada berbagai pengembangan pengukuran tingkat kesejahteraan dari sisi fisik, 
seperti Manusia Indeks Pembangunan (Indeks Pembangunan Manusia), Indeks Kualitas Hidup Fisik (Indeks Kualitas Hidup); Kebutuhan Dasar (Basic Needs); dan GNP/Kapita (Pendapatan per kapita).

Potensi penduduk di pedesaan dengan karakter kehidupan yang khas dan dibangun dari budaya yang hidup dalam masyarakat lintas generasi juga merupakan potensi dan kekuatan dalam rangka pengembangan daya tarik wisata untuk meningkatkan diversifikasi daya tarik dan daya saing. pariwisata Indonesia. Potensi daya tarik yang sebagian besar ada di pedesaan, jika mampu dikelola melalui pendekatan pembangunan pariwisata yang terpadu dan berkelanjutan, sangat memungkinkan untuk memberikan nilai tambah tidak hanya dari aspek ekologi, pendidikan dan sosial budaya. , tetapi juga dari aspek rekreatif dan rekreatif. aspek ekonomi yang bermanfaat bagi kesejahteraan bangsa, sekaligus meminimalkan tingkat kemiskinan dan kesenjangan pembangunan di pedesaan. Pengembangan pariwisata berbasis pedesaan (desa wisata) akan mendorong kegiatan ekonomi pariwisata di pedesaan yang akan mencegah urbanisasi masyarakat pedesaan ke kota. Pengembangan desa wisata akan mendorong pelestarian alam (pemandangan, sawah, sungai, danau) yang pada gilirannya akan berdampak pada pengurangan pemanasan global.

Secara konseptual, peningkatan pembangunan pariwisata dilakukan dengan memanfaatkan sumber daya dan potensi yang ada, sehingga menjadi kegiatan ekonomi yang berdampak pada perluasan dan pemerataan kesempatan berusaha/kesempatan kerja, khususnya bagi masyarakat sekitar. Selain itu, pengembangan sektor pariwisata dapat mendorong pembangunan daerah. Pada tataran operasional, pembangunan pariwisata nasional menempatkan manusia sebagai titik sentral pembangunan, baik sebagai subyek maupun obyek pembangunan. Pemanfaatan jasa ekosistem wisata alam diharapkan mampu meminimalisir potensi perusakan hutan oleh masyarakat. Apabila kegiatan wisata alam dapat memberikan manfaat ekonomi bagi masyarakat sekitar dalam arti lain yaitu dapat memenuhi pengeluaran rumah tangganya maka masyarakat akan terdorong untuk melestarikan sumber daya alam. Hal ini dikarenakan manfaat ekonomi yang mereka peroleh dari kegiatan wisata alam sangat bergantung pada kelestarian sumber daya alam dan lingkungan.

Dalam konsep pariwisata berbasis masyarakat atau disebut Community Based Tourism (CBT) terdapat lima asas, yaitu asas partisipasi masyarakat, asas pendidikan (edukasi), asas pelestarian alam, asas pelestarian budaya, dan asas pelestarian alam. prinsip ekonomi lokal. Jika prinsip community based tourism diterapkan dengan baik dan benar, maka akan 
membawa manfaat ekonomi, terutama peningkatan pendapatan masyarakat sekitar, yaitu melalui keuntungan usaha dan kesempatan kerja, pengentasan kemiskinan, pemulihan kondisi ekonomi dan mampu meningkatkan infrastruktur, selain itu juga bisa membangun jaringan. antar sektor terkait dan menciptakan pasar bagi produk pariwisata yang telah disiapkan, sehingga dapat memberikan kontribusi untuk menyeimbangkan pembangunan, keragaman ekonomi, menghilangkan ketergantungan ekonomi pada sektor tertentu, pemerataan distribusi kesempatan kerja dan peluang peningkatan pendapatan.

Permasalahan yang dihadapi pariwisata berbasis masyarakat adalah sebagai upaya memasarkan sumber daya yang telah diciptakan menjadi kawasan wisata kepada masyarakat atau konsumen agar mau berkunjung ke tempat wisata. Obyek wisata itu sendiri berfungsi untuk dapat memberikan pelayanan ruang publik sebagai tempat rekreasi, hiburan, olahraga rekreasi, memberikan kesempatan kerja dan kesempatan berusaha di bidang pariwisata bagi masyarakat sekitar obyek wisata di berbagai sektor antara lain perdagangan, transportasi, hiburan. , jasa, telekomunikasi dan sebagainya.

Berdasarkan pemahaman konsep pengembangan pariwisata di atas, maka upaya pemerintah daerah dalam mengembangkan pariwisata tidak lepas dari upaya peningkatan Pendapatan Asli Daerah (PAD) seperti retribusi masuk tempat wisata, retribusi penjualan, retribusi parkir dan perizinan usaha serta hiburan. pajak. Sedangkan perluasan peluang usaha misalnya produsen dan penjual (toko) barang cinderamata, pedagang kaki lima (PKL) dan sebagainya. Seiring dengan berkembangnya ekonomi pariwisata maka secara otomatis akan membuka lapangan pekerjaan di sektor tersebut yang pada akhirnya dapat memberikan peningkatan pendapatan masyarakat itu sendiri.

Salah satu tempat wisata terbaru di pinggiran kota Medan yang menawarkan pemandangan alam yang masih asri khas pedesaan bernama Desa Wisata Sawah Pematang Johar yang terletak di Dusun VI Rawa Badak, Kecamatan Labuhan Deli, Kabupaten Deli Serdang. Pematang Johar sendiri memiliki luas 2.200 ha, dan Desa Wisata Sawah merupakan icon baru Desa Pematang Johar Kabupaten Deli Serdang yang memiliki luas areal persawahan 1.750 ha yang dikelola menjadi icon wisata baru. Desa Pematang Johar mampu meningkatkan perekonomian masyarakat dari pendapatan pengunjung wisata. Desa Wisata Pematang Johar ini sudah banyak dikunjungi wisatawan. di lokasi ini wisatawan dapat melihat hijaunya tanaman padi khas pedesaan yang dijadikan sebagai spot foto oleh pengunjung. Pengunjung bisa mengelilingi persawahan dan tidak perlu takut menginjak lumpur karena sudah ada akses jembatan bambu yang memudahkan pengunjung untuk melihat lebih dekat 
hamparan persawahan di objek wisata ini. Bahkan di hamparan persawahan ini banyak terdapat gazebo atau gubuk bambu yang bisa dijadikan sebagai lokasi peristirahatan para pengunjung setelah lelah berkeliling Desa Wisata Sawah. Harga tiket masuk yang harus dibayar ketika memasuki objek wisata ini cukup murah yaitu Rp. 5000/orang.

Desa ini merupakan desa binaan PT. KIM (Persero) Tbk, Kepala Dinas Pemuda, Olahraga, Kebudayaan dan Pariwisata Deli Serdang, Desa Deli Serdang dan Dinas Pemberdayaan Masyarakat. Mengusung tema "Wisata Edukasi Menuju Desa Pematang Johar yang Mandiri", diharapkan dengan diluncurkannya destinasi wisata ini, masyarakat Desa Pematang Johar Deli Serdang dapat mengoptimalkan fasilitas ini menjadi pemasukan bagi desa sehingga dalam kedepannya menjadi desa wisata yang mandiri dan maju. Edukasi dilakukan agar semua pihak ikut serta menjaga dan mengamankan produk yang dikembangkan serta menumbuhkan rasa memiliki yang tinggi dari setiap komponen masyarakat. Adapun jarak yang dapat ditempuh dari pusat Kota Medan menuju objek Obyek Wisata Sawah Pematang Johar Labuhan Deli Kabupaten Deli Serdang Sumatera Utara maka perlu menempuh rute terdekat dengan jarak $36 \mathrm{~km}$. lewat jalan KL. Yos Sudarso, dan jika ingin melalui jalan dengan pilihan lain bisa melalui jalan sampali atau bisa juga melewati jalan Williem Iskandar dengan durasi perjalanan kurang lebih 37-45 menit dengan jarak tempuh 17-18 km dengan kondisi jalan yang bisa ditempuh dengan mobil atau motor pribadi dan jika ingin menggunakan kendaraan umum, jarak yang ditempuh dari simpang Martubung menuju lokasi wisata persawahan memakan waktu sekitar 15 menit dengan naik angkot Morina Nomor 79 yang bisa antar langsung ke objek lokasi langsung menuju lokasi, walaupun cukup jauh dari pusat kota Medan, namun semua akan terbayar saat sudah sampai di tempat ini.

Selain itu, berbagai promosi dalam memperkenalkan tempat wisata dilakukan oleh petugas pengelola, baik berupa media elektronik seperti melalui situs media sosial, namun kurang update dalam perkembangannya. Media televisi dapat dijadikan sebagai salah satu alternatif media yang efektif untuk beriklan atau berpromosi. Hal ini dikarenakan iklan televisi memiliki ciri khusus yaitu perpaduan antara gambar, suara dan gerak serta pesan yang disampaikan sangat menarik bagi khalayak. Media televisi dengan sifat visualnya menggunakan kombinasi warna, suara dan gerakan, sehingga iklan televisi tampil hidup dan nyata. Mempromosikan Desa Wisata Sawah menjadi icon baru di Desa Pematang Johar Kecamatan Labuhan Deli Kabupaten Deli Serdang dengan menggunakan media sosial sebagai media promosi dan pemasaran dirasa masih kurang efektif, sehingga untuk mengoptimalkan nilai 
jual pariwisata perlu dilakukan membuat metode promosi dengan menggunakan media televisi berupa iklan sebagai media promosi, sehingga nantinya dengan upaya tersebut diharapkan dapat meningkatkan dan mengembangkan jumlah kunjungan wisatawan, baik wisatawan kota medan maupun wisatawan luar kota medan yang akan berkunjung.

Tabel 1. Data Jumlah Pengunjung

\begin{tabular}{|l|l|l|}
\hline Bulan & Jumlah Hari Buka Wisata & Jumlah Pengunjung \\
\hline Januari & 31 Hari & 7.125 Orang \\
\hline Februari & 28 Hari & 6.978 Orang \\
\hline Maret & 31 Hari & 6.599 Orang \\
\hline April & 12 Hari & 2.135 Orang \\
\hline Mei & 15 Hari & 4.023 Orang \\
\hline Juni & 25 Hari & 7.534 Orang \\
\hline
\end{tabular}

Sumber: Data Internal Kampoeng Wisata Sawah (2021)

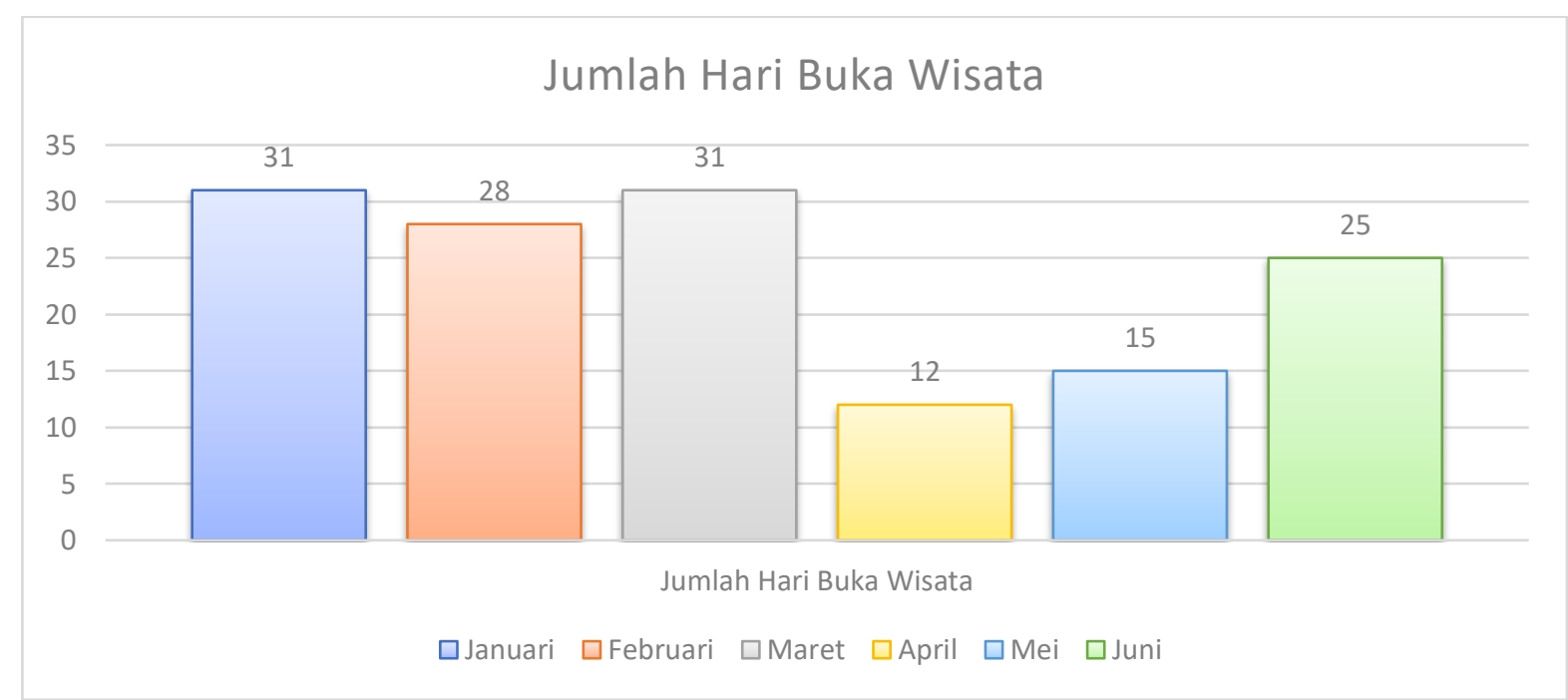

Grafik 1. Jumlah Hari Buka Wisata di Tahun 2021

Jumlah hari buka di Wisata Sawah Pematang Johar Kecamatan Labuhan Deli, Kabupaten Deli Serdang paling rendah adalah di bulan april dan Mei, hal itu disebabkan karena bulan tersebut adalah bulan puasa sehingga pada paruh awal bulan Ramadhan tempat wisata tersebut tidak beroperasional. 


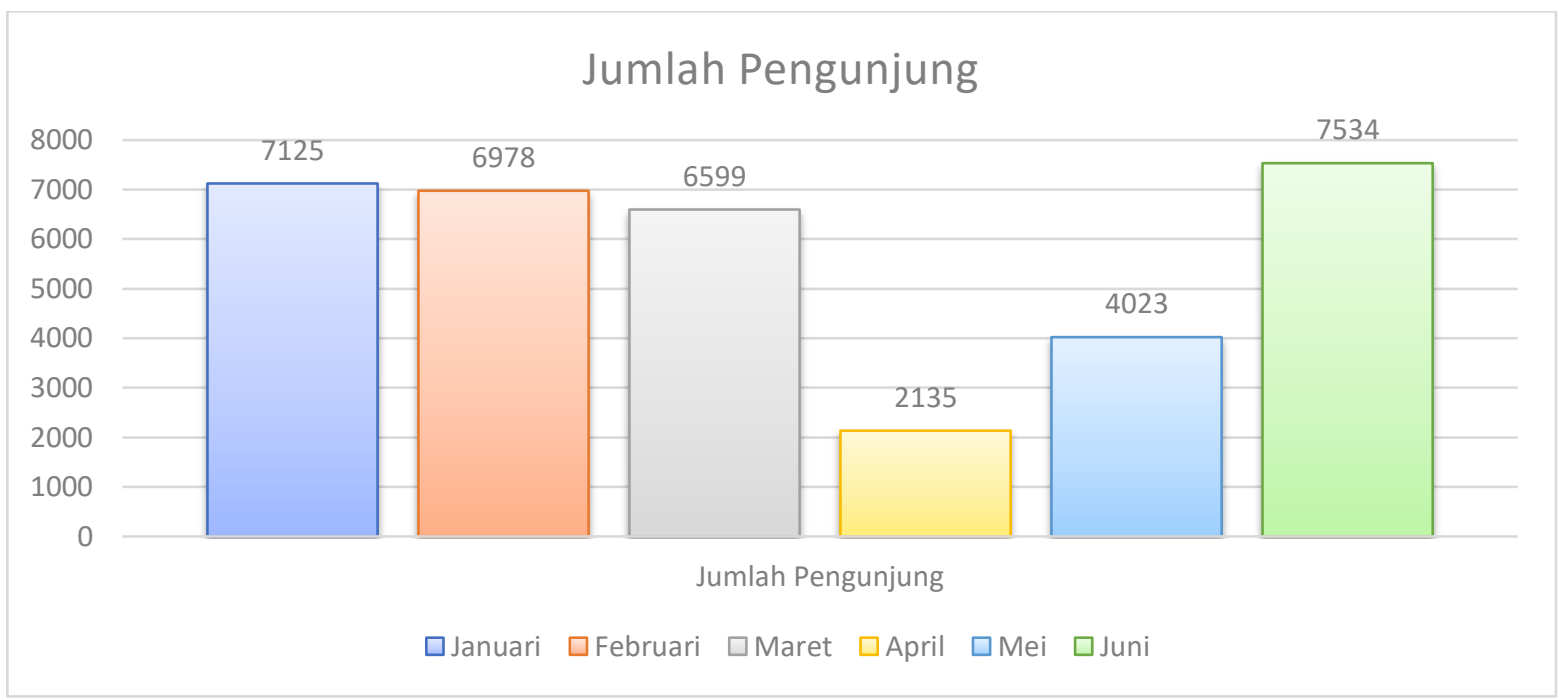

\section{Grafik 2. Jumlah Pengunjung Kampoeng Wisata Sawah}

Jumlah pengunjung Wisata Sawah Pematang Johar Kecamatan Labuhan Deli Kabupaten Deli Serdang terendah pada bulan April dan Mei, hal ini dikarenakan bulan tersebut merupakan bulan puasa dan tempat wisata pada awal bulan Ramadhan tidak beroperasi. . Saat memasuki bulan puasa, banyak orang yang mengurangi aktivitasnya di luar rumah, ditambah lagi adanya pandemi Covid-19 yang memaksa pemerintah mengeluarkan pembatasan aktivitas. Alasan lainnya, menjelang Idul Fitri, masyarakat lebih siap menyambut Idul Fitri.

Selain itu, berdasarkan wawancara awal yang dilakukan dengan salah satu staf pengelola Taman Wisata Pematang Johar Kecamatan Labuhan Deli Kabupaten Deli Serdang diketahui bahwa sejumlah pemangku kepentingan baik pemerintah maupun swasta telah bekerjasama untuk mendorong pemanfaatan objek wisata terdekat seperti: membantu pembangunan sarana dan prasarana penunjang dan promosi wisata melalui sistem pembayaran digital dan mempromosikannya melalui website milik pemerintah dan akun youtuber yang ada. Namun, di masa pandemi saat ini, keberadaan Taman Wisata Pematang Johar, Kecamatan Labuhan Deli, Kabupaten Deli Serdang tidak mendapat kunjungan sebanyak sebelum pandemi."

Memanfaatkan SDA dilaksanakan atas dasar penggunaan SDA untuk manusia. Maka semakin banyak manfaat SDA, akan berharga nilainya. Misalnya, tanah yang gembur sebagai kawasan yang memiliki potensi. Berbagai teori diatas, memanfaatkan SDA Mampu meningkatkan kesejahteraan masyarakat, yang artinya merupakan usaha agar terjadi peningkatan ekonomi rakyat saat ini yang tidak mampu mengentaskan miskin dan keterbelakangan dengan memanfaatkan sumber daya alam untuk memproduksinya. 
Sistem pertanian ramah lingkungan terintegrasi untuk sistem ekologi yang lebih luas dan fokus pada pelestarian sumber daya alam

dan keanekaragaman hayati serta menghindari segala bentuk kegiatan yang menimbulkan dampak negatif terhadap lingkungan. Taman Wisata Pematang Johar Kecamatan Labuhan Deli Kabupaten Deli Serdang yang identik dengan pertanian adalah kegiatan pemanfaatan sumber daya hayati oleh manusia untuk menghasilkan pangan, bahan baku industri, atau sumber energi, serta untuk mengelola lingkungannya. Kegiatan pemanfaatan sumber daya hayati yang termasuk dalam pertanian umumnya dipahami oleh masyarakat sebagai bercocok tanam atau bercocok tanam.

Berdasarkan wawancara yang dilakukan dengan ketua Badan Permusyawaratan Desa diketahui bahwa, sebagian besar pekerjaan yang dilakukan di sekitar Wisata Sawah Pematang Johar Kecamatan Labuhan Deli Kabupaten Deli Serdang Sumatera Utara adalah buruh tani dan petani. buruh adalah pengelola lahan orang lain dan petani sebagai pemiliknya. tanah dan pengelola. Desa Pematang Johar, Kecamatan Labuhan Deli, Kabupaten Deli Serdang berpenduduk 15.430 jiwa. 7.938 laki-laki, 7.492 perempuan, dan 4.183 keluarga. Berdasarkan pemaparan diatas maka penelitian peneliti tertarik melakukan penelitian yang berjudul "Pemanfaatan Sumber Daya Alam Hayati Sebagai Objek Wisata dan Tingkat Kesejahteraan Sekitar Lokasi Wisata (Studi Kasus: Wisata Sawah Pematang Johar Labuhan Deli Kabupaten Deli Serdang Sumatera Utara)"

\section{METODE PENELITIAN}

Penelitian ini merupakan penelitian lapangan dengan menggunakan pendekatan penelitian kualitatif, yaitu penelitian yang bersifat deskriptif dan cenderung menggunakan analisis. Penelitian ini dilakukan untuk mengetahui pemanfaatan sumber daya alam sebagai objek wisata dan tingkat kesejahteraan masyarakat sekitar lokasi wisata yang terletak di Jalan Johar Raya Gg. Tanah Wakaf, Jl. Dusun VI, Pematang Johar, Kec. Labuhan Deli, Kabupaten Deli Serdang, Sumatera Utara 20373. Penelitian ini dilaksanakan pada bulan Agustus sampai dengan Oktober 2021. Dan objek penelitian ini adalah Obyek Wisata Pematang Johar. Teknik analisis yang digunakan adalah reduksi data, penyajian data, dan penarikan kesimpulan. Alat ukur keabsahan data adalah pengecekan data peneliti dengan menggunakan teknik pengecekan keabsahan data yaitu triangulasi. Ada jenis triangulasi yaitu triangulasi sumber untuk menguji kredibilitas data dilakukan dengan cara mengecek data yang telah diperoleh melalui beberapa sumber, triangulasi teknis digunakan untuk menguji kredibilitas data dilakukan dengan cara mengecek data ke sumber 
yang sama dengan teknik yang berbeda. Misalnya data diperoleh dengan wawancara kemudian diperiksa dengan observasi, triangulasi waktu, waktu juga sering mempengaruhi kredibilitas data. Pengumpulan data dilakukan dengan teknik wawancara pada pagi hari saat narasumber masih segar, tidak banyak masalah akan memberikan data yang lebih valid sehingga lebih kredibel.

\section{HASIL DAN PEMBAHASAN}

\section{Daya Dukung Fisik Serta Potensi Wisata Sawah Dalam Menunjang Kegiatan Pariwisata}

Dalam rencana pengembangan Desa Wisata Pematang Johar, Kecamatan Labuhan Deli, Kabupaten Deli Serdang, Provinsi Sumatera Utara sebagai kawasan agrowisata, peluangnya adalah perubahan tren pariwisata dari mass tourism (pergerakan orang dalam jumlah besar dengan tujuan menghabiskan waktu luang di satu tempat) menjadi pariwisata yang berkualitas (dapat dicapai dengan meningkatkan kualitas pariwisata serta kenyamanan dan keamanan destinasi wisata) dengan menerapkan kebersihan, sertifikasi kesehatan, keselamatan, dan lingkungan. Tren wisata dengan konsep back to nature tourism saat ini sedang banyak diminati. Untuk mendukung pengembangan desa wisata dimulai dengan tahap perencanaan yang didalamnya terdapat pengembangan sumber daya manusia, sumber daya alam, lokasi strategis, promosi yang baik serta dukungan sarana dan prasarana.

\section{Faktor manusia}

Sumber Daya Manusia, mendukung keberhasilan pembangunan desa wisata, jika sumber daya manusia yang mengelolanya kompeten di bidangnya tidak hanya secara kuantitas tetapi juga kualitas dalam pengembangan desa wisata persawahan, dan dapat memberikan partisipasi dalam pengembangan persawahan. desa wisata. Bentuk partisipasi yang dimiliki oleh Sumber Daya Manusia pada masyarakat lokal desa wisata persawahan adalah:

Tabel 2. Bentuk Partisipasi Masyarakat

\begin{tabular}{|l|l|l|}
\hline No. & Bentuk Partisipasi & Keterangan \\
\hline 1. & Partisipasi Fikiran & $\begin{array}{l}\text { Masyarakat setempat memberikan } \\
\text { partisipasi dalam pertemuan atau rapat } \\
\text { rutin yang bertujuan untuk memajukan } \\
\text { desa wisata }\end{array}$ \\
\hline 2. & Partisipasi Tenaga & $\begin{array}{l}\text { Partisipasi tenaga yang dilakukan adalah } \\
\text { didalam kegiatan berupa membantu } \\
\text { dalam proses perbaikan serta } \\
\text { pembangunan desa dan menolong yang }\end{array}$ \\
\hline
\end{tabular}




\begin{tabular}{|l|l|l|}
\hline & & $\begin{array}{l}\text { membutuhkan khususnya untuk } \\
\text { kepentingan pengembangan objek wisata }\end{array}$ \\
\hline 3. & $\begin{array}{l}\text { Partisipasi } \\
\text { Keterampilan dan } \\
\text { Kemahiran }\end{array}$ & $\begin{array}{l}\text { Partisipan memiliki upaya untuk } \\
\text { mendorong aneka ragam bentuk usaha } \\
\text { industri, mempelajari budaya } \\
\text { masyarakat setempat dan apabila ada } \\
\text { pertunjukan di desa berusaha untuk } \\
\text { menampilkan nya. }\end{array}$ \\
\hline 4. & Partisipasi Sosial & $\begin{array}{l}\text { partisipasi ditempatkan sebagai pihak } \\
\text { diluar proses pembangunan dalam } \\
\text { konsultasi atau pengambilan keputusan } \\
\text { dalam semua tahapan siklus proyek } \\
\text { pembangunan dari evaluasi kebutuhan } \\
\text { sampai penilaian, pemantauan, evaluasi } \\
\text { dan implementasi. }\end{array}$ \\
\hline
\end{tabular}

Pada sumber daya manusia yaitu dalam kegiatan agrowisata di persawahan perlu dilakukan identifikasi kemampuan dalam mengelola desa wisata. Pemberdayaan Sumber Daya Manusia merupakan suatu keadaan kegiatan yang harus ada dalam suatu organisasi. Dalam mengembangkan Tourism Awareness, diperlukan pelatihan dalam suatu organisasi sebagai upaya pengembangan sumber daya manusia, yang merupakan siklus yang harus dilakukan secara terus menerus. Namun sulit bagi SDM untuk memiliki keahlian khusus di bidang pengembangan pariwisata, sehingga perlu diprioritaskan solusi. Berdasarkan wawancara yang dilakukan dengan staf desa selaku pengelola Desa Wisata Pematang Johar Kecamatan Labuhan Deli Kabupaten Deli Serdang Provinsi Sumatera Utara mengatakan jika dengan melakukan dan menumbuhkan kesadaran pariwisata bagi masyarakat lokal desa wisata yaitu dengan memberikan pelayanan yang baik dan memahami keinginan mereka yang bepergian atau berkunjung, serta dengan membuat wisatawan merasa aman, karena dengan melihat pemandangan yang sejuk ditambah dengan pedesaan Susana yang tertib, lokasi wisata yang bersih, indah, masyarakat yang ramah, sehingga setiap pengunjung tidak cukup hanya sekali saja mengunjungi tempat wisata ini, serta akses jalan yang memudahkan wisatawan untuk mengunjungi lokasi wisata".Pengelolaan Desa Wisata Pematang Johar Kecamatan Labuhan Deli Kabupaten Deli Serdang Provinsi Sumatera Utara yang masih relatif baru juga masih sangat sederhana dalam pengelolaannya, yang meliputi: 


\section{Pedagang}

Para pedagang yang ikut berjualan di kawasan Desa Wisata Sawah Pematang Johar Kecamatan Labuhan Deli Kabupaten Deli Serdang Provinsi Sumatera Utara adalah masyarakat sekitar Desa Pematang Johar dalam melaksanakannya mengelola memberikan ruang pada rakyat agar berdagang. di tempat-tempat yang diizinkan. Tempat mereka berdagang juga diserahkan kepada masing-masing. Peran pengurus sebagai fasilitator dan dalam pemungutan iuran pengurus berperan penting dalam menentukannya yaitu Rp. 5.000/hari untuk setiap pedagang. Uang ini sudah termasuk dalam biaya keamanan dan kebersihan.

Para pedagang ini menjual beberapa barang diantaranya menjual minuman, baik dingin maupun panas, makanan termasuk makanan tradisional khas masyarakat setempat. Bakso, mie ayam, sop, mainan anak

Berdasarkan wawancara yang dilakukan dengan pedagang selaku masyarakat sekitar yang berjualan di sekitar lokasi yaitu "bahwa keberadaan objek wisata ini berdampak baik dan adanya peningkatan kesejahteraan ekonomi dalam peningkatan pendapatan". Wisata ini juga membantu perekonomian keluarga, dan karena wisata ini membantu dalam meningkatkan perekonomian menjadi stabil. Ada penghasilan tambahan dalam membantu keuangan keluarga. Obyek wisata berpengaruh dalam hal pendapatan dan membantu masyarakat sekitar, dan untuk kondisi keuangan akhir-akhir ini mengalami penurunan. Obyek wisata berpengaruh dalam hal pendapatan dan membantu masyarakat sekitar, dan untuk kondisi keuangan akhir-akhir ini mengalami penurunan.

2. Tempat Parkir

Penyediaan lahan parkir di Desa Wisata Pematang Johar Kecamatan Labuhan Deli Kabupaten Deli Serdang Provinsi Sumatera Utara cukup dan cukup luas untuk kendaraan roda dua dan roda empat seperti mobil pribadi dan untuk harga parkir roda dua kendaraan bermotor sangat terjangkau yaitu sekitar Rp. 2.000,- dan untuk mobil cukup terjangkau yaitu sekitar 5.000.

3. Pelayanan

Pelayanan yang diberikan oleh pengelola desa wisata Pematang Johar Kecamatan Labuhan Deli Kabupaten Deli Serdang Provinsi Sumatera Utara sudah cukup baik untuk memenuhi keinginan wisatawan seperti dalam melayani setiap tamu dengan keramahan sehingga memberikan rasa nyaman. kenyamanan bagi wisatawan yang berkunjung. 


\section{Faktor Sumber Daya Alam}

Selain menjadi sumber pendapatan dan membuka lapangan pekerjaan bagi penduduk desa, desa wisata dapat menjadi insentif bagi penduduk desa untuk lebih meningkatkan kesadaran dan minat mereka terhadap seni dan tradisi budaya warisan leluhur mereka dan lingkungan tempat mereka tinggal.

Ada 4 aspek pemanfaatan sumber daya alam yaitu, milik umum (open access), milik negara (state), milik pribadi atau perseorangan (private) dan milik bersama (communal). Pemanfaatan sumber daya alam di Desa Wisata Pematang Johar Kecamatan Labuhan Deli Kabupaten Deli Serdang Provinsi Sumatera Utara memiliki sumber daya alam yang berbeda-beda, yaitu:

1) Pemanfaatan sumber daya alam di Desa Wisata Pematang Johar, Kecamatan Labuhan Deli, Kabupaten Deli Serdang, Provinsi Sumatera Utara. Pemanfaatan sumber daya alam di Desa Wisata Pematang Johar Kecamatan Labuhan Deli Kabupaten Deli Serdang Provinsi Sumatera Utara merupakan milik umum (open access) dan milik bersama, karena sumber daya alam yang ada di Wisata Sawah Pematang Johar Kecamatan Labuhan Deli Kabupaten Deli Serdang, Provinsi Sumatera Utara dimanfaatkan dan dikelola bersama, yang memiliki potensi sumber daya alam yang dapat dimanfaatkan oleh masyarakat sekitar dan pengunjung. Potensi yang dikembangkan adalah membantu ketahanan ekonomi dan ketahanan pangan secara bersama karena pemanfaatan sumber daya alam yang dimiliki oleh masyarakat dan masyarakat setempat dapat memanfaatkannya.

2) Pengembangan sumber daya alam di Desa Wisata Pematang Johar, Kecamatan Labuhan Deli, Kabupaten Deli Serdang, Provinsi Sumatera Utara

\section{Sarana dan Prasarana}

Pengembangan sarana dan prasarana merupakan salah satu aspek penting yang perlu diperhatikan dalam pengembangan agrowisata. Hal ini terkait erat dengan keberadaan wisatawan yang ditentukan oleh kemudahan seperti, kemudahan akomodasi dan transportasi serta kesadaran masyarakat sekitar untuk berkreasi. Kondisi yang kondusif dan alami serta bersih, aman dan nyaman menjadi prioritas yang perlu diciptakan. Kondisi di Desa Wisata Pematang Johar, Kecamatan Labuhan Deli, Kabupaten Deli Serdang, Provinsi Sumatera Utara relatif baik, dikarenakan adanya sarana peribadatan misalnya musola yang diadakan agar tamu dapat beribadah sambil menikmati keindahannya. dari persawahan, toilet yang disediakan juga cukup baik dan 
bersih, dan infrastruktur menuju lokasi juga cukup baik dengan akses jalan yang baik.

\section{Promosi dan Pengelolaan}

Adanya promosi mempermudah rakyat luas mencari tahu Tempat Wisata di Pematang Johar Kecamatan Labuhan Deli Kabupaten Deli Serdang Provinsi Sumatera Utara.

Selain promosi, manajemen juga diperlukan dalam pengembangan suatu daya tarik wisata. Manajemen yang baik membutuhkan kerja keras yang diimbangi dengan kesungguhan tim manajemen yaitu mereka yang benarbenar serius di bidangnya. Manajemen juga harus lebih memperhatikan apa yang diinginkan pengunjung agar atraksi yang ditawarkan mampu menarik pengunjung untuk datang kembali yaitu tingkat keamanan, kenyamanan dan kebersihannya.

Dari hasil penelitian yang dilakukan peneliti di atas, Desa Wisata Pematang Johar Kecamatan Labuhan Deli Kabupaten Deli Serdang Provinsi Sumatera Utara dilihat dari kondisi geografis keragaman pemandangan dengan mewujudkan konsep alam dan keindahan. dari hamparan luas persawahan hijau hingga kuning. Adanya modal dari BUMDes dan potensi alam berupa persawahan tidak hanya dapat dinikmati oleh petani dan masyarakat sekitar tetapi juga dapat dinikmati oleh masyarakat pada umumnya sebagai objek wisata. Selain ditunjang dengan sumber daya alam yang baik yang masih terjaga dengan baik dan jauh dari suasana perkotaan yang membuat pengunjung nyaman saat berada di lokasi ini, ditambah lagi banyaknya spot foto yang disediakan untuk pengunjung, sumber daya manusia juga tidak kalah ikut berperan. dalam mendukung berupa kesadaran dan kemauan masyarakat setempat dalam pengembangan pariwisata di Desa Wisata Pematang Johar Kecamatan Labuhan Deli Kabupaten Deli Serdang Provinsi Sumatera Utara. Salah satu daya tarik dari objek wisata ini adalah dalam membangun komitmen akan pentingnya melestarikan pariwisata yang melihat kondisi ekonomi masyarakat sekitar yaitu yang ikut berjualan di sekitar lokasi adalah masyarakat sekitar objek lokasi selain meningkatkan tingkat ekonomi masyarakat sekitar tetapi juga dapat melestarikan daya tarik wisata.

Selain faktor tersebut, kondisi sosial budaya masyarakat sekitar Desa Wisata Pematang Johar Kecamatan Labuhan Deli Kabupaten Deli Serdang Provinsi Sumatera Utara memiliki sikap ramah, bersahabat dan berbudaya yang memiliki pengaruh dominan sebagai daya tarik pengunjung. . Hal ini tidak lepas dari dukungan Bapak Sudarman S.Pd selaku Kepala Desa Pematang Johar Kecamatan Labuhan Deli Kabupaten Deli Serdang Provinsi Sumatera Utara serta atas dukungan Dinas Kebudayaan dan Pariwisata yang berperan 
dalam proses pemasaran dan pendapatan tambahan untuk dana awal dalam proses pengembangan wisata sawah., dukungan yang diberikan berupa dukungan materil dan dukungan moril. Terjalin kerjasama yang baik antara instansi USU (Universitas Sumatera Utara), UMSU Universitas Muhammadiyah Sumatera Industri, PT. KIM (Kawasan Industri Medan), Bank Sumut, dan pihak lain yang memberikan bantuan berupa dana, ide konsep wisata persawahan. Adanya kerjasama yang baik dari instansi tersebut memberikan pengaruh yang baik terhadap objek lokasi Wisata Sawah Pematang Johar Kecamatan Labuhan Deli Kabupaten Deli Serdang Provinsi Sumatera Utara.

Jika ada upaya pendukung, pasti ada upaya yang dijadikan kendala yaitu berupa pandemi Covid-19 dan kecemburuan sosial yang terjadi di masyarakat yang tidak termasuk dalam proses kegiatan desa wisata ini.

Pandemi Covid-19 sebagai faktor penghambat dalam proses pembangunan Desa Wisata Pematang Johar Kecamatan Labuhan Deli Kabupaten Deli Serdang Provinsi Sumatera Utara kendalanya dana sudah lama turun karena kondisi saat ini. dimana instansi terkait lebih menekankan pada penanganan Covid-19. Selain itu, pihak pengelola tidak menyerah dalam proses pembangunan dan terus mencari dana pemasukan berupa tiket masuk dan parkir untuk meningkatkan sarana prasarana wisata.

Faktor penghambat selanjutnya adalah dari masyarakat itu sendiri, mengenai adanya kecemburuan sosial yang terjadi di masyarakat dan merasa jika tidak diikutsertakan dalam proses Desa Wisata Pematang Johar Kecamatan Labuhan Deli Kabupaten Deli Serdang Provinsi Sumatera Utara, awalnya masyarakat sekitar tidak setuju dengan hal ini. dibukanya proses pariwisata ini, karena mereka takut di masa depan lingkungan hidup dan kehidupan sosial mereka akan rusak.

\section{Pembangunan Fasilitas Wisata Sawah Mampu Memberi Kesejahteraan Masyarakat Di Sekitar Lokasi Wisata}

Menurut Boediono, pertumbuhan ekonomi didefinisikan sebagai proses peningkatan output per kapita dalam jangka panjang, yang menekankan pada tiga aspek, yaitu: proses, output per kapita, dan jangka panjang.

Pertumbuhan ekonomi sebagai suatu "proses" mengandung pengertian bahwa pertumbuhan ekonomi bukanlah gambaran perekonomian pada suatu waktu tertentu, tetapi dilihat dari aspek dinamis suatu perekonomian, yaitu bagaimana ekonomi berkembang dan berubah dari waktu ke waktu. Dalam kaitannya dengan output per kapita pada periode tersebut atau tidak. Jika terjadi peningkatan, maka akan terjadi pertumbuhan ekonomi, begitu pula sebaliknya. 
Pembangunan ekonomi kerakyatan ditujukan untuk meningkatkan kesejahteraan masyarakat Desa Wisata Pematang Johar Kecamatan Labuhan Deli Kabupaten Deli Serdang Provinsi Sumatera Utara. Prinsip dasarnya adalah mengembangkan kemampuan masyarakat Desa Wisata Pematang Johar secara mandiri dalam upaya mencapai peningkatan kesejahteraan. Sedangkan pendekatan utama adalah apresiasi terhadap kedaulatan dan kemampuan masyarakat Desa Wisata Pematang Johar itu sendiri, yang dilanjutkan dengan upaya penguatan dan peningkatan keberdayaan mereka. Daya saing, peningkatan, produktivitas, efisiensi, penguasaan pasar, atau variabel ekonomi lainnya hanyalah indikator perantara menuju tujuan akhir, keberlanjutan kegiatan ekonomi rakyat, peningkatan kemandirian, dan akhirnya peningkatan kesejahteraan rakyat secara keseluruhan.

Selain berdampak pada perekonomian, perkembangan pariwisata juga berdampak pada sosial budaya, oleh karena itu perkembangan pariwisata secara langsung dan tidak langsung akan berdampak pada budaya yang dimiliki masyarakat sekitar desa wisata. Sehingga keberadaan sosial budaya ini akan berdampak pada perlindungan wisata persawahan dan diharapkan mampu menjaga daya tarik wisata yang dilakukan oleh masyarakat sekitar, pemerintah daerah dan wisatawan yang berkunjung ke lokasi wisata. Hal ini bisa dibuktikan jika hingga saat ini kondisi persawahan Pematang Johar, Kecamatan Labuhan Deli, Kabupaten Deli Serdang, Provinsi Sumatera Utara masih asri dan tidak rusak. Pemerintah daerah Deli Serdang selalu mengutamakan persawahan sebagai branding.

\section{KESIMPULAN}

Adapun daya dukung fisik dan potensi wisata persawahan dalam menunjang kegiatan pariwisata, sumber daya manusia memegang peranan penting dalam mengelola desa wisata, sumber daya alam yaitu dalam pemanfaatan sumber daya alam di Desa Wisata Pematang Johar adalah milik umum ( akses terbuka). ) dan milik bersama, sarana dan prasarana seperti sarana peribadatan seperti mushola yang disediakan oleh pengelola desa wisata agar pengunjung tetap dapat beribadah sambil menikmati keindahan persawahan, toilet yang disediakan juga cukup baik dan bersih, dan infrastruktur menuju lokasi juga cukup baik dengan akses jalan yang baik. Serta promosi yang tidak hanya dilakukan dengan promosi langsung, tetapi dapat juga menggunakan media massa, seperti facebook, instagram dan youtube, serta website resmi Dinas Pemuda, Olahraga, Kebudayaan, Pariwisata, Deli Serdang agar siapapun dapat dengan mudah mengakses tempat wisata ini. 
Pembangunan sarana wisata persawahan mampu memberikan kesejahteraan bagi masyarakat sekitar lokasi wisata, yang terlihat dari banyaknya lapangan pekerjaan seperti tukang parkir, pedagang, petugas kebersihan sehingga mengurangi pengangguran di Desa Wisata Pematang Johar Labuhan Deli Kecamatan, Kabupaten Deli Serdang, Provinsi Sumatera Utara. itu sendiri, yang terlihat dari meningkatnya perekonomian pendapatan masyarakat sekitar lokasi serta nilai-nilai sosial budaya yang terus berkembang di masyarakat seperti masyarakat lokal yang ramah dan berbudaya, religi, pendidikan dan kesenian, dengan mengutamakan nilai-nilai budaya keamanan, ketertiban dan keindahan.

\section{REFERENCES}

Abdurrahman Fathoni, Metodologi Penelitian \& Teknik Penyusunan Skripsi. (Jakarta: PT.Rineka Cipta.,2011)

Adiwarman A. Karim, Ekonomi Makro Islam, (Jakarta: PT RajaGrafindo Persada, 2012)

Azhari Akmal Tarigan, Tafsir Ayat-ayat Ekonomi Tela'ah atas Simpul-Simpul Ekonomi dan Bisnis dalam Al-Qur'an, (Medan: FEBI UIN-Su Press, 2016),

Bambang Sunaryo, Kebijakan Pembangunan Destinasi Pariwisata Konsep dan Aplikasinya di Indonesia, (Yogyakarta: Gava Media, 2013)

Bintoro dan Daryanto, “Manajemen Penilaian Kinerja Karyawan. Cetakan 1”, (Yogyakarta: Gava Media, 2017)

Edi Suharto, Membangun Masyarakat Memberdayakan Rakyat (Kajian Strategis Pembangunan Kesejahteraan Sosial \& Pekerjaan Sosial, (Bandung:PT.Refika Aditama,2014),

Edy Sutrisno, “Manajemen Sumber Daya Manusia(Cetakan ke tujuh)”, (Jakarta:

Kencana Prenada Media Group, 2015)

Edy Sutrisno, “Manajemen Sumber Daya Manusia”, (Jakarta: Kencana Prenada Media Group, 2016),

Husein Umar, Metode Penelitian Untuk Skripsi dan Tesis Bisnis, (Jakarta: PT Raja Grafindo Persada, 2016

I Nyoman Sukma Arida, Buku Ajar Pariwisata Berkelanjutan, (Bali:Sustainpress,2012)

Isnaini Harahap et, all, Hadis-Hadis Ekonomi: edisi pertama, (Medan: Kencana, 2015)

Isnaini Harahap, Ekonomi Pembangunan: Pendekatan Disipliner, (Medan:Perdana Publishing, 2018) 
Journal Economy And Currency Study (JECS)

Volume 3, Issue 2, July 2021

Page 94-110

Jimmy Gaol L, "A to Z Human Capital : Manajemen Sumber Daya Manusia:, (Jakarta: PT. Grasindo, 2014)

Kementerian Pariwisata dan Ekonomi Kreatif, tentang Rencana Strategis 20202024.

Koesnadi Hardjasoemantri, "Hukum Tata Lingkungan” , (Yogyakarta: Gadjah Mada University Press, 2006)

Mila Badriyah, “Manajemen Sumber Daya Manusia”, (Bandung: Pustaka Setia, 2015)

Mohamad Ridwan, Perencanaan dan Pengembangan Pariwisata, (PT SOFMEDIA: Medan, 2012)

M. Ghufron, "Rekonstruksi Paradigma Fikih Lingkugan”, (Surabaya: IAIN SA Press, 2012)

Mukhlis dan Mustafa Lutfi, "Hukum Administrasi Lingkungan Kontemporer", (Malang: Setara Press, 2010),

Nandi, Pariwisata dan Pengembangan Sumberdaya Manusia, Jurnal Pendidikan Geografi, Vol. 8, No. 1, 2008

Nur Ahmadi Bi Rahmani, Metodologi Penelitian Ekonomi, (Medan: FEBI-UINSU Press, 2016)

Peraturan Pemerintah Nomor 50 Tahun 2011, tentang Rencana Induk Pembangunan Kepariwisataan Nasional Tahun 2010-2025

Sedarmayanti, Sumber daya manusia dan produktivitas kerja, (Bandung, CV Mandiri Maju, 2009)

Sihombing, T. P, Studi Kelayakan Pengembangan Usaha Pengolahan Kopi Arabika (Studi Kasus PT. Sumatera Speciality Coffees), (Bogor : Institut Pertanian Bogor, 2011)

Sugiama, A. G., Ecotourism : Pengembangan Pariwisata berbasis konservasi alam. (Bandung: Guardaya Intimarta, 2011)

Sugiyono, Metode Penelitian Kombinasi : Mixed Methods, (Bandung: CV Alfabeta, 2018)

Sugiyono. Metode Penelitian Kuantitaif, Kualitatif dan $R \mathcal{E} D$, (Bandung : Alfabeta,2019)

Suharsimi Arikunto, Prosedur Penelitian: Suatu Pendekatan Praktik. (Jakarta: Rineka Cipata, 2013) 